\title{
Impact Of Organisational Politics On Job Dissatisfaction And Turnover Intention: An Application Of Social Exchange Theory On Employees Working In Zimbabwean Small And Medium Enterprises (SMEs)
}

Elizabeth Chinomona, Vaal University of Technology, South Africa

Teboho Mantebele Mofokeng, Vaal University of Technology, South Africa

\begin{abstract}
Organizational politics has been seen as detrimental to the smooth running of firms. Despite increasing awareness of the importance of managing the negative effects of organizational politics at the workplace, research on consequences relating to employees' perceptions of the same in small and medium enterprises (SMEs) in Africa, especially Zimbabwe in particular, has received little attention. This paper uses Structural Equation Modelling (SEM) to test the causal relationships between the three variables which are organizational politics, job dissatisfaction and turnover intention. Amos 23.0 software has been used as it is the current software on the market for SEM usage. Therefore, using data of 154 SMEs in Zimbabwe, this paper examines the effects of employees' perceptions of organizational politics on job dissatisfaction and turnover intentions. All the posited three hypotheses were supported by the sample data. Managerial implications of the findings are discussed and limitations and future research directions are indicated.
\end{abstract}

Keywords: Social Exchange Theory; Small and Medium Enterprises; Organizational Politics; Job Dissatisfaction; Turnover Intentions

\section{INTRODUCTION}

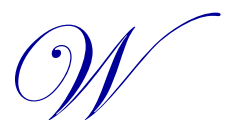

hat often accompanies firm's success is fortitude paired with hard work. Known as human capital (Boswell, Ren \& Hinrichs 2008), employees fuel the willpower of firms, function as a backbone and solidify a firm's competitive stance. For this reason, firms have much responsibility for employees. This is evident in firms' directing efforts towards understanding employees especially their intention to turnover (Tett \& Meyer 1993). Since the objective of firms is to realize success, employee turnover intention suits to be an important subject given that it helps firms to detect if they are working at maximum potential to retain the employees as recruiting new employees its very costly for the organisation (Mor Barak, Levin, Nissly \& Lane 2006). The causes of employee turnover intention are therefore central concepts considering they alter an employee's perception regarding job occupation. One key cause found to affect employees psychologically is the engagement of politics within the firm (Rosen \& Hochwarter 2014). Though there is contention about the consequences of organisational politics, the dominating deduction is that it is a negative phenomenon (Saleem 2015). It is maintained that the engagement of politics within a firm creates dysfunction (Chang, Rosen \& Levy 2009) and discontentment (Rosen \& Levy 2013), leaving employees feeling constricted in terms of accomplishing both personal and professional goals (Ferris, Russ \& Fandt 1989). Naturally, such a feeling predisposes employees to dissatisfaction. What may result from job dissatisfaction is careless and ignorant behaviour (Farrell 1983) followed by intent to turnover (Zhou \& George 2001). As a consequence, firms risk parting with a valuable human resource and weakening firm performance subsequently (Zhou \& George 2001; Jiang, Baker \& Frazier 2009). 
An unconstructive workforce is detrimental especially for a developing country like Zimbabwe where much of the country's progress is reliant on superior performance of firms. In its efforts to improve, Zimbabwe instigated economic reforms. However, these restructuring programmes have had a severe impact on the country's welfare (Kowero \& Mabungu 2006). Lower labour force participation has been one of its consequences where workers feel less inclined to work due to strict labour regulations imposed by the country's government (Djankov \& Ramalho 2009). What's more, organisational politics have become a habitual conduct (Utami, Bangun \& Lantu 2014), prompting employees to perceive the workplace as being inequitable, immoral and unreasonable (Gandz \& Murray 1980). Such working conditions exacerbate the harsh working circumstances where discrimination, underpay, exploitation and ill safety also prevail within firms of developing countries (Djankov\& Ramalho 2009). The resulting ramification is often employee dissatisfaction. Muchinsky and Morrow (1980) and Trevor (2001) assert that dissatisfied employees are likely to have an intention to turnover. Since unemployment is high in Zimbabwe (Kowero \& Mabungu 2006) it is unlikely that turnover may be an immediate reaction by dissatisfied employees. However, with foreign competition and imports having increased within the country (Marquette 1997), not much value can be reaped from the tenure of dissatisfied employees but unproductivity (Zhou \& George 2001).

The concept of turnover intention has attracted the attention of researchers and practitioners alike. Dinger, Thatcher, Stepina and Craig (2011) affirm that it is important to understand the dimensions around employee turnover intent so that costs can be minimised, invaluable employees can be retained and turnover rates can be diminished. While many factors compel quitting behaviour (Kim \& Mor Barak 2015), organisational politics has been one of those implicated (Rosen \& Hochwater 2014). What's more, dissatisfied employees have been found to exhibit turnover tendency as well (Lee, Mitchell, Wise \& Fireman 1996). Although research confirms that organisational politics and job dissatisfaction have an impact on turnover intention, it seems to be deficient with regards to how job dissatisfaction mediates the relationship between organisational politics and turnover intention. As such, the current study seeks to bridge this gap in research. In particular, the study seeks to investigate from a social exchange perspective, the predicting role of organisational politics and the mediating role of job dissatisfaction on employee turnover intention. Therefore, the study's objectives are twofold, that is:

1. To examine the influence of organisational politics on job dissatisfaction; and

2. To examine the impact of job dissatisfaction on turnover intention.

The insight that is to be brought to light is expected to make a contribution to the existing body of turnover literature. Small and Medium Enterprises are also likely to gain knowledge of how they can gratify their labour force and hence strengthen their business practices.

The rest of the paper is organized as follows. Firstly, the theory of social exchange is drawn upon to support the study's proposition. Thereafter, literature for each of the research constructs is reviewed. The study's research model is provided and hypotheses are developed subsequently. What follows is an account of the study's methodology as well as a discussion on findings. Lastly, inferences are provided.

\section{LITERATURE REVIEW}

\section{Social Exchange Theory}

Originally, social exchange theory was developed for the purpose of examining human behaviour (Homans 1958). However soon after, it was applied in the attempts to grasp organisational behaviour (Blau, 1964; Emerson 1962). Emerson (1976) asserts that the theory of social exchange has the supposition that there are certain norms that direct behaviour and attitude. These customs steer the exchange process (Cropanzano \& Mitchell 2005) and if fair, satisfaction, support and mutual values would classify the relationship, resulting in trust (Lee, Capella, Taylor, Luo \& Gabler 2014) which paves the way for quality, stability and the tenure of the exchange relationship (Blau, 1964; Cropanzano \& Mitchell 2005; Cropanzano \& Rupp 2008; Rodriguez \& Wilson 2002; Zaheer, McEvily \& Perrone 1998). As Andrews, Witt and Kacmar (2003) and Chang et al. (2009) affirmed that organisational politics have become widespread within the business environment, this suggests that politics are a norm that governs behaviour within most organisations. Since organisational politics often impact negatively on employees (Saleem, 2015) they are perceived as being unfair (Perrewé, Brymer \& Stepina 1991; Ross 2005) which according to social exchange 
theory, positions the exchange relationship at risk, contradictory to the benefit reaped from fairness (Blau 1964). Understandably, unfairness incites dissatisfaction. Lai, Singh, Alshwer and Shaffer (2014) maintain that, from a social exchange perspective, individuals are likely to part ways with the relationship if they perceive it as being unbeneficial to them. This implies that when employees are dissatisfied, they are likely to have an intention to turnover, thus a threat to discontinue the exchange relationship that is between the organisation and the employee.

\section{Small and Medium Enterprises}

The term SMEs covers a wide range of definitions and measures, varying from country to country, region to region and among the sources reporting SME statistics. Some of the commonly used criteria are the number of employees, total net assets and sales and investment level (Chinomona, Lin, Wang \& Cheng 2010; Chang, Chang, Ho, Yen \& Chiang 2011; Chinomona \& Pretorius 2011). For the purposes of this study, a small and medium enterprise refers to a registered enterprise with a maximum of 100 employees and an annual turnover in sales of a maximum of 830000 US dollars (Machipisa 1998; Nyoni 2002). In Zimbabwe there are two sectors of SMEs: manufacturing and service SMEs. SMEs in Zimbabwe are regarded as the engine of economic growth and major instruments of employment generation (Chipika \& Wilson 2006). Notwithstanding this, SMEs in Zimbabwe, as in most African countries, still suffer from a lack of resources, which impedes their expansion and influence in the market (Gono 2009).

\section{Organisational Politics}

It can be concurred that the concept of organisational politics has relevance in that it affects organisational behaviour (Hochwarter 2003) and therefore business practices and the corporate world in general. Given that organisational politics negatively impinge on business performance (Bangun, Mangkuprawira \& Djohar 2011) and hence economic development, it has been a focal research area (Yilmaza, Özer \& Günlük 2014) with scholars striving to decipher the dynamism underlying the phenomenon. While some argue that organisational politics may be meaningful for example, it may facilitate recognition, admiration by others, personal and organisational goal achievement and selfcontrol and self-realization (Gandz et al., 1980; Kumar \& Ghadially 1989; Bacharach 2005; Drory \& Vigoda-Gadot, 2010) an often prevailing conclusion is that fundamentally, it's destructive (Saleem 2015).

Rosen et al. (2014) accentuates that politics at work elicit stress in which hostile attitudes, diminished welfare and desertion are manifested. While inefficiency is a resulting consequence, an even detrimental ramification is that employee goal pursuit is deterred (Eisenhardt \& Bourgeois 1988; Kumar et al., 1989; Ferris, Frink, Bhawuk \& Zhou 1996; Vigoda 2003;) and thus career advancement which demoralises a country's labour force in general. While competitiveness and the will for power and success are some drivers for organisational politics (Drory \& VigodaGadot 2010) the outcome of it is usually some self-fulfilment as above mentioned for those who encourage it and job dissatisfaction, withdrawal, absenteeism and turnover intentions (Gilmore, Ferris, Dulebohn \& Harrell-Cook 1996; Harrell-Cook, Ferris \& Dulebohn 1999; Maslyn \& Fedor 1998; Randall, Cropanzano, Bormann \& Birjulin 1999; Rosen et al., 2014), for those suppressed by it. Witt, Andrews and Kacmar (2000) describe organisational politics as the attempt of organisational members to "either directly or indirectly influence other members by means not sanctioned by formal standard operating procedures or informal norms, in an attempt to achieve personal or group objectives". According to Fleming and Spicer (2008) and Gotsis and Kortezi (2011) organisational politics are "intentional acts of influence, actions, even tactics on influencing decision making". However for the purpose of this study, the construct is defined according to Mintzberg (1983), who avow that organisational politics are behaviours that are intended to promote self-interests with disregard to or at the cost of organisational goals. The construct is unidimensional and it will be measured as such.

\section{Job Dissatisfaction}

Job dissatisfaction is acknowledged as a reaction to impairment of one's quality of work life. While this response affects employees, organisations often experience an impact as well. This impact often comes in a form of poor performance, low quality and disorder with regard to standard operations (Jiang et al., 2009). It is perhaps for this reason that there has been a great need to understand and improve the outlook of labour (Jiang et al., 2011). 
Though job dissatisfaction is trailed by careless and inattentive behaviour, Farrell (1983) asserts that such reaction can serve as a warning to management of reduced organisational efficiency. Research has long hinted that job dissatisfaction may actually be meaningful under certain circumstances. In adding to Farrel's (1983) assertion that dissatisfaction may serve as caution, March and Simon (1958), Staw (1984) and Van Gundy (1987) affirm that dissatisfaction can serve as an impetus for employees to try to improve their working conditions by instigating new and better ways of doing things. Discerning new and better ways of doing things is reminiscent especially given that presently, firms are driven by change, creativity and innovation (Ohme \& Zacher 2015). However, what is often a consequence of job dissatisfaction is not advancement but improper behaviour followed by job turnover (Zhou \& George 2001). Evidently, re-analysing and re-adjusting working conditions and organisational behaviour could be a practical solution in the effort to alleviate job dissatisfaction. Hersch and Stone (1990) describe job dissatisfaction as a response to poor working conditions. The construct is unidimensional and the study defines it as a destructive response that results in exit or neglect (Farrell 1983).

\section{Turnover Intention}

It is conceived that the certainty emanated by economic conditions will fuel an employee's willingness to turnover employment (Cotton \& Tuttle 1986; Park, Ofori-Dankwa \& Bishop 1994). Though healthier economic conditions may provide more opportunities in terms of career advancement, the corollary for firms may be besiege in terms of losses in institutional knowledge and increases in hiring and training (Moynihan \& Pandey 2007). In research, employee retention has been cited as a difficulty for firms (Boswell et al., 2008). Dinger et al., (2011) understand that, as a way forward, firms should strive to make sense of the dimensions that drive quitting behaviour. While better economic conditions could be one, high workloads, inadequate support, minimal income and insufficient training have also been found to be conducive to employee turnover intention (Kim \& Mor Barak 2015).

In developing countries, the informal sector has been identified as a segment in which there is more employment (Mizunoya \& Mitra 2012). This sector is distinguished as an "easy entry sector" that is friendly in terms of entering and income provision (Fields 2005). It is therefore reasonable to assume that this could be another basis behind employee intention to quit. Although a number of firms resort to increasing wages and reinforcing training as way of alleviating employee intention to turnover (Velenchik 1997), Jiang et al. (2009) argues that actual employee turnover can be positive for firms as it will allow for the reception of new ideas and a rapid diffusion of technological knowledge. However, for firms operating in a country like Zimbabwe, such constructive outcomes are difficult to reap given the stringent labour regulations that govern the formal sector (Djankov\& Ramalho 2009). What therefore befalls organisations in most instances is loss of capacity and productivity. Research indicates that turnover intention does correlate with actual turnover (Steensma, Van Breukelen \& Sturm 2004; Byrne 2005; Chen, $\mathrm{Su}, \mathrm{Lo}$, Chiu, Hu \& Shieh 2014). Other withdrawal behaviour such as absenteeism have also been found to be associated with the construct (Chang, Wang \& Huang 2013) while satisfaction and commitment have been identified as being relative as well (Bluedorn 1982; Hollenbeck \& Williams 1986; Tett \& Meyer 1993). Tett and Meyer, (1993) define turnover intention as "a conscious and deliberate wilfulness to leave the organisation". According to

DeTienne, Agle, Phillips and Ingerson (2012), turnover intention is merely whether an employee has the aim of ending his or her employment. The construct is unidimensional and the study defines it as a behavioural propensity of employees to attempt to part ways with their employment firm (Chen et al., 2014).

\section{Conceptual Model and Hypothesis Development}

Deducting from the literature, the study's conceptual model is developed. Figure 1 below is a depiction of the proposed model. Noticeably, it illustrates an indirect causal relationship where the predicting role of organisational politics and the presumed outcome i.e. turnover intention is mediated by job dissatisfaction. Employing social exchange theory as a theoretical base, the study puts forward that organisational politics and job dissatisfaction are likely to have an influence on employee turnover intention. Three hypotheses are drawn, each indicated by an $\mathrm{H}$ and a number. They are developed hereafter. 
Figure 1. Conceptual model

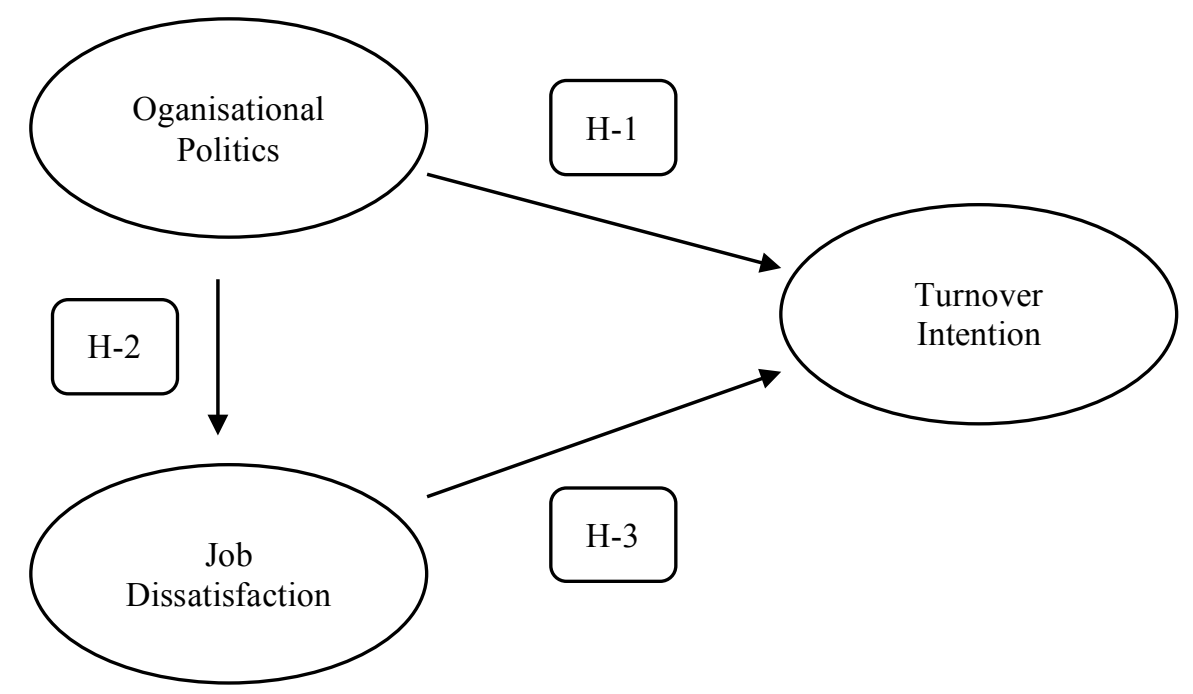

Drawing from the literature and the study's proposition, three hypotheses are developed:

\section{Organisational Politics and Turnover Intention}

Employee retention has been acknowledged as one of the main crises confronting firms (Boswell et al., 2008). It can be conceived that a causal factor may be organisational politics which ironically have been identified as a common phenomenon within organisations today (Utami et al. 2014; Chang, Rosen \& Levy 2009). Chang, Wang and Huang (2013) assert that employees are prone to resort to withdrawal behaviour prior to exhibiting intention to turnover. This coincides with the outcomes of organisational politics such as lack of involvement and low productivity (Andrews, Witt, \& Kacmar 2003; Rosen et al. 2014). It can be accepted that such employee exertion is attributed by the practice of politics within organisations which generate employee dissatisfaction and reduce commitment (Vigoda, 2000; Indartono, 2009; Indartono \& Chen, 2011; Kacmar, Bozen, Carlson \& Anthony 1999). When withdrawal behaviour much like these are exhibited, it is expected that employees may begin to have intentions to quit. The correlation between organisational politics and turnover intention has been supported in a study by Kacmar and Baron (1999). The study puts forth a similar conjecture. In particular, the study proposes that organisational politics within Zimbabwean SMEs will have an impact on employee intention to turnover. Deducing from the literature, the study therefore hypothesizes that:

H1: Organisational politics within Zimbabwean SMEs has a positive relationship with employee turnover intention.

\section{Organisational Politics and Job Dissatisfaction}

Organisational politics and job dissatisfaction are relevant concepts in that they temper with employee cognition and therefore their behaviour. Firms have high regard for superior performance and stability. For this reason, a great effort has been imposed on the comprehension and improvement of labour attitude (Jiang et al. 2009). Earlier studies provide an indication that organisational politics has been a chief focus area (Mayes \& Allen 1977; Zahra, 1987). Politics are perceived by employees as being unfair, immoral, unreasonable and detrimental (Gandz et al.1980). It is evident that their engagement within organisations is conducive to unethical behaviour. What often stems from unethical behaviour is ambiguity where employees feel that there is incoherence in terms of internal practices (Harris, Harris \& Harvey 2007). As a result, employees become predisposed to dissatisfaction for the reason that they feel that goal accomplishment is improbable with just ability and hard work alone (Rosen et al. 2013). Previous studies corroborate the relationship between organisational politics and job dissatisfaction Kacmar et al. 1999; Vigoda 2000; Indartono 2009; Indartono \& Chen 2011). Accordingly, the current study puts forward a similar 
conjecture. In particular, the study proposes that the engagement of organisational politics within Zimbabwean SMEs will lead to the dissatisfaction of employees regarding their job. Through inferring from the literature and observing the empirical evidence, the study thus hypothesizes that:

H2: Organisational politics within Zimbabwean SMEs has a positive relationship with job dissatisfaction of employees

\section{Job Dissatisfaction and Turnover Intention}

Job dissatisfaction and turnover intention have been given much attention (Hom \& Kinicki, 2001; Kruzich, Mienko \& Courtney 2014) considering the implication they have for firms. Dissatisfaction is conceived to result in careless and ignorant behaviour (Farrell 1983) while turnover intention has been found to be associated with lacking organisational performance (Morbarak, Levin, Nissly \& Lane 2006). Poor working conditions and an unethical organisational climate have been identified as two circumstances amongst those that cause job dissatisfaction (Aquino \& Thau 2009; Bowling \& Beehr 2006; Schwepker 2001). When employees are dissatisfied, it is likely that they would impart withdrawal behaviour such as absenteeism (Steers \& Rhodes 1978; Organ 1988; Hom, Caranikas-Walker, Prussia \& Griffeth, 1992). Chang et al. (2013) asserts that dissatisfied employees who act with absenteeism in response are likely to have unacknowledged turnover intentions. Once turnover intentions are comprehended, it is said that employees will become subject to a "withdrawal cognition process": thoughts of turning over, the intention to look for alternative employment elsewhere and the intention to self-terminate employment (Carmeli \& Weisberg 2006). It is thus evident that employee intention to turnover is an attempt that undergoes sequential stages. Sheth and Parvatiyar (1995) provide support for the correlation between job dissatisfaction and turnover intention. The study puts forth a similar proposition. In particular, the study posits that job dissatisfaction among employees working in Zimbabwean SMEs is likely to lead to their intention to turnover. Drawing from the literature and the empirical evidence, the study hypothesizes that:

H3: Job dissatisfaction among employees working in Zimbabwean SMEs has a positive relationship with their intentions to turnover

\section{MEASUREMENT INSTRUMENTS}

Previous studies have been used to design the questionnaires and slight changes were made to fit the current study. A nine-item scale was used to measure employees' perceptions of organizational politics and was adapted from the previous study by Kacmar et al. (1999), while a five-item scale to measure employees' job dissatisfaction was adapted from Datienne et al. (2012). On turnover intentions, a five-item scale was used from Wayne, Shore and Liden (1997). 5-point Likert-type scales was used in this study that was anchored by $1=$ strongly disagree to $5=$ strongly agree to express the degree of agreement (Chinomona \& Chinomona 2013).

Table 1. Sample demographic characteristics

\begin{tabular}{l|c|c}
\hline Gender & Frequency & Percentage \\
\hline Male & 88 & $57 \%$ \\
\hline Female & 66 & $43 \%$ \\
\hline Total & $\mathbf{1 5 4}$ & $\mathbf{1 0 0 \%}$ \\
\hline Age & & $20 \%$ \\
\hline$\leqq 30$ & 30 & $58 \%$ \\
\hline $31-60$ & 90 & $22 \%$ \\
\hline$\geqq 60$ & 34 & $\mathbf{1 0 0 \%}$ \\
\hline Total & $\mathbf{1 5 4}$ & \\
\hline Marital status & & $65 \%$ \\
\hline Married & 100 & $35 \%$ \\
\hline Single & 54 & $\mathbf{1 0 0 \%}$ \\
\hline Total & $\mathbf{1 5 4}$ & \\
\hline
\end{tabular}




\section{DESCRIPTIVE STATISTICS}

Questionnaires were to taken to diverse relevant SMEs in Zimbabwe for providing answers. 200 questionnaires were distributed, 165 were returned and out of these 165 questionnaires, only 154 were in working order. This produced a usable response rate of about $77 \%$. Descriptive statistics in Table 1 shows the gender, marital status, and age of employees in the company. As indicated in Table 1, this study shows that males dominate the SMEs sector and constitute $57 \%$ of the employees. The utmost energetic age group in SMEs is that between 31- 60 years which comprise $58 \%$ of the total employees, followed by those below 60 years and then above 60 years, constituting $22 \%$ and $20 \%$ respectively. Employees who are married occupy 65 and the remainder are single.

Table 2. Accuracy analysis statistics

\begin{tabular}{|c|c|c|c|c|c|c|c|c|}
\hline \multirow{2}{*}{\multicolumn{2}{|c|}{ Research constructs }} & \multicolumn{2}{|c|}{ Descriptive statistics } & \multicolumn{2}{|c|}{ Cronbach's test } & \multirow{2}{*}{ CR } & \multirow{2}{*}{ AVE } & \multirow{2}{*}{ Factor loadings } \\
\hline & & Mean & SD & Item-total & $\alpha$ value & & & \\
\hline \multirow{9}{*}{$\begin{array}{c}\text { Organisational } \\
\text { politics }\end{array}$} & OP1 & \multirow{9}{*}{3.92} & \multirow{9}{*}{0.72} & 0.538 & \multirow{9}{*}{0.716} & \multirow{9}{*}{0.78} & \multirow{9}{*}{0.72} & $0.715^{\mathrm{c}}$ \\
\hline & OP2 & & & 0.571 & & & & $0.747^{\mathrm{c}}$ \\
\hline & OP3 & & & 0.646 & & & & $0.667^{\mathrm{c}}$ \\
\hline & OP4 & & & 0.562 & & & & $0.593^{\mathrm{c}}$ \\
\hline & OP5 & & & 0.540 & & & & $0.703^{\mathrm{c}}$ \\
\hline & OP6 & & & 0.423 & & & & 0.834 \\
\hline & OP7 & & & 0.634 & & & & $0.755^{\mathrm{c}}$ \\
\hline & OP8 & & & 0.661 & & & & $0.849^{c}$ \\
\hline & OP9 & & & 0.674 & & & & $0.843^{c}$ \\
\hline \multirow{5}{*}{$\begin{array}{c}\text { Job } \\
\text { dissatisfaction }\end{array}$} & JD1 & \multirow{5}{*}{4.05} & \multirow{5}{*}{0.81} & 0.576 & \multirow{5}{*}{0.609} & \multirow{5}{*}{0.68} & \multirow{5}{*}{0.61} & $0.533^{\mathrm{c}}$ \\
\hline & JD2 & & & 0.648 & & & & $0.781^{\mathrm{c}}$ \\
\hline & JD3 & & & 0.679 & & & & $0.737^{\mathrm{c}}$ \\
\hline & JD4 & & & 0.559 & & & & $0.560^{\mathrm{c}}$ \\
\hline & JD5 & & & 0.543 & & & & $0.537^{\mathrm{c}}$ \\
\hline \multirow{5}{*}{$\begin{array}{l}\text { Turnover } \\
\text { intention }\end{array}$} & TN1 & \multirow{5}{*}{3.91} & \multirow{5}{*}{0.74} & 0.524 & \multirow{5}{*}{0.719} & \multirow{5}{*}{0.79} & \multirow{5}{*}{0.71} & $0.951^{\mathrm{c}}$ \\
\hline & TN2 & & & 0.544 & & & & $0.689^{\mathrm{c}}$ \\
\hline & TN3 & & & 0.559 & & & & $0.720^{\mathrm{c}}$ \\
\hline & TN4 & & & 0.602 & & & & $0.626^{\mathrm{c}}$ \\
\hline & TN5 & & & 0.363 & & & & 0.503 \\
\hline
\end{tabular}

\section{Model Fit Results}

Confirmatory factor analysis (CFA) was done to scrutinise the reliability, convergent validity and discriminant validity of the multi-item construct measures. "Overall acceptable CFA model fit indices used in this study included: the $\chi^{2} /(\mathrm{df})$ (Chi-Square/Degree of Freedom) value equal to or less than 3.00, the CFI (Comparative Fit Index) value equal to or higher than 0,90 , Tucker and Lewis Index (TLI) value equal to or higher than 0,90 , the Incremental Index of Fit (IFI) value equal to or higher than 0.90 and the Root Mean Square Error of Approximation (RMSEA) value equal to or less than 0.08" (Chinomona \& Chinomona 2013:20). Recommended statistics for the final overall model assessment showed an acceptable fit of the measurement model to the data, that is: $\chi^{2} /(\mathrm{df})=2,000, \mathrm{CFI}=0,901$, TLI $=0,910, \mathrm{IFI}=0,925$ and $\mathrm{RMSEA}=0,067$.

Table 2 above shows the loading of each items on their particular construct. The least value for each respective item loadings for the research constructs is 0,503 . Therefore, all the individual item loadings exceeded the recommended value of 0,5 (Anderson and Gerbing 1988). This indicates that all the measurement instruments are acceptable and reliable since all the individual items converged well and with more than $50 \%$ of each item's variance shared with its respective construct (Fraering \& Minor 2006).

Composite reliabilities (CR) and average variance extracted (AVE) for each construct were also computed using the formulae proposed by Fornell and Lacker (1981:22) i.e. 


$$
\mathrm{CR} \eta=(\Sigma \lambda \mathrm{yi}) 2 /[(\Sigma \lambda \mathrm{yi}) 2+(\Sigma \varepsilon \mathrm{i})]
$$

where

$\mathrm{CR} \eta=$ Composite reliability, $(\Sigma \lambda \mathrm{yi}) 2=$ Square of the summation of the factor loadings; $(\Sigma \varepsilon \mathrm{i})=$ Summation of error variances.

$$
\mathrm{V \eta}=\Sigma \lambda \mathrm{yi} 2 /(\Sigma \lambda \mathrm{yi} 2+\Sigma \varepsilon \mathrm{i})
$$

where

$V \eta=$ Average Variance Extracted (AVE); $\Sigma \lambda y i 2=$ Summation of the squared of factor loadings; $\Sigma \varepsilon i=$ Summation of error variances".

As shown from the results shown in Table 2, the least composite reliability (CR) value of 0,68 is well above the recommended 0.6 (Hulland 1999), while the lowest obtained average variance extracted (AVE) value of 0,61 is also above the recommended 0.5 (Fraering \& Minor 2006). This indicates that convergent validity was achieved and also this further confirms an excellent internal consistency and reliability of the measurement instruments used. "As such, all pairs of constructs revealed an adequate level of discriminant validity (see Table 2). By and large, these results provided evidence for acceptable levels of research scale reliability" (Chinomona \& Chinomona 2013:20).

\section{Structural Equation Modeling and Research Hypothesis Testing Assessment}

The results for CFA are good and therefore, Structural Equation Modelling (SEM) was then performed. The hypotheses testing by path modeling was done to determine the strength or weakness of the causal relationships. Results of SEM shows that all the research model fit statistics were within the tolerable ranges, i.e., $\chi^{2} /(\mathrm{df})=2,802$, $\mathrm{CFI}=0,900, \mathrm{TLI}=0,906, \mathrm{IFI}=0,915$, and RMSEA $=0,078$. The individual hypothesis testing results were done and the path coefficients for $\mathrm{H} 1, \mathrm{H} 2, \mathrm{H} 3$ are 0,290, 0,607 and 0.516 respectively. All hypothesis coefficients are significant at a confidence level ( $\mathrm{p}$ value) of 0,001 . Therefore, these results provide support for all the proposed three hypotheses (Chinomona \& Chinomona 2013).

\begin{tabular}{|c|c|c|c|}
\hline RESEARCH CONSTRUCT & OP & JD & TN \\
\hline $\mathrm{OP}$ & 1.000 & & \\
\hline JD & $0.357 * *$ & 1.000 & \\
\hline TN & $0.519 * *$ & $0.457 * *$ & 1.000 \\
\hline
\end{tabular}

Table 3. Correlations between constructs

\section{CORRELATION MATRIX}

One of the methods used to check on the discriminant validity of the research constructs was the evaluation of whether the correlations among latent constructs were less than 0.6 As indicated in Table 3, the inter-correlation values for all paired latent variables are less than 0.6 , therefore, indicating the existence of discriminant validity. However, since the correlation values of JD and OP is 0.357 , as well as TN and OP is 0.519 , TN and JD is 0.457 which is within the recommended threshold (Bryman \& Bell 2007) see Table 3, it provides evidence of discriminant validity.

\section{DISCUSSION OF THE RESULTS}

SET was used in this study to provide a theoretical grounding for the conceptual framework that pursues to illustrate the effects of organizational politics on job dissatisfaction and on employees' turnover intentions in the SME business atmosphere in Zimbabwe. In this study job dissatisfaction affects turnover intention in a more significant way than other because the pat co-efficient is 0.607 which is the highest. This is followed by the fact that organisational politics affects job dissatisfaction a more significant way. The path co-efficient is 0.516 . The higher 
the organisational politics in an organisation the more the job dissatisfaction of the employees. Last but not least, organizational politics positively leads to turnover intention in a significant way. The path co-efficient for this relationship is 0.290 which is the least among the three hypotheses. However all the relationships were significant at a p-value of 0.001. Zimbabwe's SME sector was used as a sampling framework for data collection to confirm the proposed hypotheses of the research framework. In this study the results for data analysis support the research hypotheses proposed. Overall, this provides support to the research propositions that employees' perceptions of organizational politics positively influence their turnover intentions and also job dissatisfaction in the SME setting (Chinomona \& Chinomona 2013).

\section{IMPLICATIONS OF THE RESEARCH}

This study has both academic and practical implications. "On the academic front, two contributions are made. Firstly, an attempt was successfully made to apply the Social Exchange Theory in order to explicate important human resources management phenomena in the small business field. Secondly, this study examined an important issue in a neglected research context, that is, SMEs in a developing country of Southern Africa. Therefore, this study has expanded the existing literature on SME human resources management to developing countries" (Chinomona \& Chinomona 2013: 22).

On the practical side, given the fact that employees' perceptions of organizational politics leads to job dissatisfaction and turnover intention, managers in the SMEs sector are advised to adopt measures that are directed at reducing the adverse impact of organizational politics in order to retain employees as it is more expensive to replace employees than retaining the ones that a company has. Such measures might include transparent rules, regulations and policies in which everyone has to follow without hesitation. "Managers are also encouraged to reward desired behaviours that follow the code of conduct while ignoring undesirable behaviours that promote negative organizational politicking at the workplace" (Chinomona \& Chinomona 2013:22).

\section{LIMITATIONS AND FUTURE RESEARCH DIRECTIONS}

This study has limitations and suggested future directions that opens up room for future research. Non-managerial employees were used as respondents in the study and the results might be more robust if both managerial and nonmanagerial were used as respondents in the study. Also comparing the data from managerial and non-managerial might be more enlightening and added different value and flavour to the research. Therefore, preceding studies might consider collecting data from these two sides for empirical investigation. While this study focused on Zimbabwe only, extending this study to other African countries like South Africa, Namibia, Nigeria, Tanzania and Malawi is also another possible future research direction that might enable comparisons of results with the current study findings. On top of this, future research might also deliberate on examining the effects of employee perceptions of organizational politics on other outcomes such as employee perception of equity, workplace spirituality and organizational commitment.

\section{AUTHOR BIOGRAPHIES}

Dr Elizabeth Chinomona is a married woman with three children. Her first degree is from the University of Zimbabwe and her Masters is from National Cheng Kung University in Taiwan. She completed her PHD with Vaal University of Technology this year. Currently she is working as a lecturer at Vaal University of Technology in the Logistics Department, South Africa. Research is her passion as she has always learned a lot from it and also disseminate knowledge to others. Research areas include entrepreneurship, marketing, supply chain and human resources management. Email: chakubvae@hotmail.com.

Teboho Mantebele Mofokeng was born in South Africa in the year 1990. He completed his Matric in 2008 at Hoerskool Harrismith and then moved on to begin his course in Logistics Management at the Vaal University of Technology (VUT) the following year. In the year 2012 he graduated his National Diploma and went on to do his Btech in the very same year, in the same course and university. He then enrolled for his Master's degree in 2013 with VUT again. He developed a passion for research and has since published academic papers with three of the most renowned individuals in Academia. Email: mofokengtebogo@gmail.com. 


\section{REFERENCES}

Anderson, J.C. \& Gerbing, D.W. (1988). Structural equation modeling in practice: A review and recommended two- step approach. Psychology Bulletin 103: 411-423.

Andrews, M.C., Witt, L.A. \& Kacmar, K.M. (2003). The interactive effects of organizational politics and exchange ideology on manager ratings of retention. Journal of Vocational Behavior, 62:357-369.

Aquino, K. \& Thau, S. (2009). Workplace victimization: Aggression from the target's perspective. Annual Review of Psychology, 60(1):717-741.

Bacharach, S. (2005). Get them on your side: Win support, convert skeptics, get results. La Crosse, WI: Platinum Press.

Bangun, Y.R., Mangkuprawira, S. \& Djohar, S. (2011). Modelling Organizational Capability through leadership, organizational politics and culture and its impact to business performance- proceedings. Pan Pacific Conference Bali 2011.

Blau, P.M. (1964). Exchange and power in social life. New York: John Wiley.

Bluedorn, A.C. (1982). A unified model of turnover from organizations. Human Relations, 35:135-153.

Boswell, W.R., Ren, L.R. \& Hinrichs, A.T. (2008). Voluntary employee turnover: Determinants, processes, and future directions. In Barling, J. \& Cooper, C.L., eds. The SAGE Handbook of Organizational Behavior, Volume One: Micro Approaches. London: Sage, pp. 196-216.

Bowling, N.A. \& Beehr, T.A. (2006). Workplace harassment from the victim's perspective: A theoretical model and metaanalysis. Journal of Applied Physiology, 91(5):998-1012.

Byrne, Z. (2005). Fairness reduces the negative effects of organizational politics on turnover intentions, citizenship behavior and job performance. Journal of Business and Psychology, 20(2):175-200.

Carmeli, A. \& Weisberg, J. (2006). Exploring turnover intentions among three professional groups of employees. Human Resource Development International, 9(2):191-206.

Chang, D., Rosen, C. \& Levy, P. (2009). The relationship between perceptions of organizational politics and employee attitudes, strain, and behavior: A meta-analytic examination. Academy of Management Journal, 52:779-801.

Chang, ML, Chang, SI, Ho, CT, Yen, DC \& Chiang, MC. (2011). Effects of IS characteristics on e-business success factors of Small and Medium- sized enterprises. Computers in Human Behaviour, 27: 2129-2140.

Chang, W-J.A., Wang, Y-S. \& Huang, T-C. (2013). Work design-related antecedents of turnover intention: A multilevel approach. Human Resource Management, 52:1-26.

Chen, M-L., Su, Z-Y., Lo, C-L., Chiu, C-H., Hu, Y-H. \& Shieh, T-Y. (2014). An empirical study on the factors influencing the turnover intention of dentists in hospitals in Taiwan. Journal of Dental Sciences, 9:332-344.

Chinomona, R, Lin, J, Wang, M \& Cheng, J. (2010). Soft power and Desirable Relationship Outcomes in Zimbabwe Distribution Channels. African Journal of Business, 11(2):20-55.

Chinomona, R \& Pretorious, M. (2011). SME manufacturers cooperation and Dependency on major dealers Expert power in Distribution Channels. South Africa Journal of Economics and Management Sciences, 12(2):170-186.

Chinomona, R \& Chinomona, E. (2013). The influence of emplyees' perceptions of organizational politics on turnover intentions in Zimbabwe's SME sector. South African Journal of Business Management, 44(2):15-24.

Chipika, S \& Wilson, G. (2006). Enabling Technology learning among light engineering SMEs in Zimbabwe through networking. Journal of Technovation, 26(8): 969-979.

Cotton, J.L. \& Tuttle, J.M. (1986). Employee turnover: A meta-analysis and review with implications for research. Academy of Management Review, 11:55-70.

Cropanzano, R. \& Mitchell, M.S. (2005). Social exchange theory: An interdisciplinary review. Journal of Management, 31(6):874-900.

Cropanzano, R. \& Rupp, D.E. (2008). Social exchange theory and organizational justice: Job performance, citizenship behaviors, multiple foci, and a historical integration of two literatures. In Gilliland, S.W., Skarlicki, D.P. \& Steiner, D.D., eds. Research in social issues in management: Justice, morality, and social responsibility. Greenwich CT: Information Age Publishing, pp. 63-99.

Detienne, K.B., Agle, B.R., Phillips, J.C. \& Ingerson, M.C. (2012). The impact of moral stress compared to other stressors on employee fatigue, job satisfaction, and turnover: An empirical investigation. Journal of Business Ethics, 110(3):377391.

Dinger, M., Thatcher, J.B., Stepina, L.P. \& Craig, K. (2011). The grass is always greener on the other side: A test of present and alternative job utility on IT professionals' turnover. IEEE Transactions on Engineering Management, 99:1-15.

Djankov, S. \& Ramalho, R. (2009). Employment laws in developing countries. Journal of Comparative Economics, 37:3-13.

Drory, A. \& Vigoda-Gadot, E. (2010). Organizational politics and human resource management: A typology and the Israeli experience. Human Resource Management Review, 20:194-202.

Eisenhardt, K.M. \& Bourgeois, L.J. III. (1988). Politics of strategic decision making in high-velocity environments: Toward a midrange theory. Academy of Management Journal, 31:737-770.

Emerson, R.M. (1962). Power-dependence relations. American Sociological Review, 27(1): 31-41.

Emerson, R.M. (1976). Social exchange theory. Annual Review of Sociology, 2:335-362.

Farrell, D. (1983). Exit, Voice, Loyalty, and Neglect as responses to job dissatisfaction: A Multidimensional scaling study. The Academy of Management Journal, 26(4):596-607. 
Ferris, G.R., Frink, D.D., Bhawuk, D.P.S. \& Zhou, J. (1996). Reactions of diverse groups to politics in the workplace. Journal of Management, 22:23-44.

Ferris, G., Russ, G. \& Fandt, P. (1989). Politics in organizations. In Giacalone, R. \& Rosenfeld, P., eds. Impression management in organizations. Newbury Park, CA: Sage, pp. 143-170.

Fields, G. (2005). A guide to multi sector labour market models. Social Protection Discussion Paper Series No. 505. Washington, DC: The World Bank.

Fleming, P. \& SPICER, A. (2008). Beyond power and resistance: New approaches to organizational politics. Management Communication Quarterly, 21(3):301-309.

Fornell, C \& Larcker, D. (1981). Structural equation models with unobservable variables and measurement error.Journal of Marketing Research 18 (1): 39-50.

Fraering, M., \& Minor, M.S. (2006). Sense of Community: An Exploratory Study of US Consumers of Financial Services. International Journal of Bank Marketing, 24(5): 284-306.

Gandz, J. \& Murray, V.V. (1980). The experience of workplace politics. Academy of Management Journal, 23:237-251.

Gilmore, D.C., Ferris, G.R., Dulebohn, J.H. \& Harrell-Cook, G. (1996). Organizational politics and employee attendance. Group and Organization Management, 21:481-494.

Gono, G. (2009). Zimbabwe's Casino Economy. Extraordinary measures for extraordinary challenges. Harare: Zimbabwe Publishing House.

Gotsis, G. \& Kortezi, Z. (2011). Bounded self-interest: A basis for constructive organizational politics. Management Research Review, 34(4):450-476.

Harrell-Cook, G., Ferris, G.R. \& Dulebohn, J.H. (1999). Political behaviors as moderators of the perceptions of organizational politics-work outcomes relationships. Journal of Organizational Behavior, 20:1093-1105.

Harris, B.R., Harris, J.K. \& Harvey, P. (2007). A Test of competing models of the relationship among perceptions of organizational politics, perceived organizational support, and individual outcomes. The Journal of Social Psychology, 147(6):631-655.

Hersch, J. \& Stone, J.A. (1990). Is Union Job Dissatisfaction Real? The Journal of Human Resources, 25(4):736-751.

Hochwarter, W. (2003). The interactive effects of pro-political behavior and politics perceptions on job satisfaction and affective commitment. Journal of Applied Social Psychology, 33:1360-1378.

Hollenbeck, J.R. \& Williams, C.R. (1986). Turnover functionality versus turnover frequency: A note on work attitudes and organizational effectiveness. Journal of Applied Psychology, 71:606-611.

Hom, P.W., Caranikas-Walker, F., Prussia, G.E. \& Griffeth, R.W. (1992). A meta-analytic structural equations analysis of a model of employee turnover. Journal of Applied Psychology, 77:890-909.

Hom, P.W. \& Kinicki, A.J. (2001). Toward a greater understanding of how dissatisfaction drives employee turnover. The Academy of Management Journal, 44(5):975-987.

Homans, G.C. (1958). Social behavior as exchange. American Journal of Sociology, 63:597-606.

Hulland, J. (1999). Use of Partial Least Squares (PLS) in strategic management research: A Review of four recent studies. Strategic Management Journal, 20(2):195-204.

Indartono, S. (2009). Mediation effect of trust on the relationship between perception of organizational politics and commitment. Journal Administration Business, 5(2):160.

Indartono, S. \& Chen, C-H.V. (2011). Moderating effect of tenure and gender relationship between perception of organizational politics and commitment and trust. South Asian Journal of Management, 18(1):7-36.

Jiang, B., Baker, R.C. \& Frazier, G.V. (2009). An analysis of job dissatisfaction and turnover to reduce global supply chain risk: Evidence from China. Journal of Operations Management, 27:169-184.

Kacmar, K.M., Bozeman, D.P., Carlson, D.S. \& Anthony, W.P. (1999). An examination of the perceptions of organizational politics model: Replication and extension. Human Relations, 52(3):383-416.

Kacmar, K.M. \& Baron, R.A. (1999). Organizational politics: The state of the field, links to related processes, and an agenda for future research. Research in Personnel and Human Resources Management, 17:1-39.

Kim, A. \& Mor Barak, M.E. (2015). The mediating roles of leader-member exchange and perceived organizational support in the role stress-turnover intention relationship among child welfare workers: A longitudinal analysis. Children and Youth Services Review, 52:135-143.

Kowero, G. \& Mabungu, R. (2006). Macroeconomic policies and industrial wood processing and trade in Zimbabwe. Forest Policy and Economics, 8:22-34.

Kruzich, J.M., Mienko, J.A. \& Courtney, M.E. (2014). Individual and work group influences on turnover intention among public child welfare workers: The effects of work group psychological safety. Children and Youth Services Review, 42:20-27.

Kumar, P. \& Ghadially, R. (1989). Organizational politics and its effects on members of organizations. Human Relations, 42:305-314.

Lai, C., Singh, B., Alshwer, A.A. \& Shaffer, M.A. (2014). Building and leveraging interpersonal trust within and across MNE subsidiaries: A Social Exchange Perspective. Journal of International Management, 20:312-326.

Lee, J.J., Capella, M.L., Taylor, C.R., Luo, M. \& Gabler, C.B. (2014). The financial impact of loyalty programs in the hotel industry: A social exchange theory perspective. Journal of Business Research, 67:2139-2146.

Lee, T.W., Mitchell, T.R., Wise, L. \& Fireman, S. (1996). An unfolding model of voluntary employee turnover. Academy of 
Management Journal, 39(1):5-36.

Machipisa, L. (1998). Developing the Focused Entrepreneur. [On-line]. Available at: http://72.14.207.104/search?q=cache:UiMJ1N2HYJ.www.ipsnews.net/domainl ogin. Date accessed 6/04/2006.

March, J. \& Simon, H. (1958). Organizations. New York: Wiley.

Marquette, C.M. (1997). Current poverty, structural adjustment, and drought in Zimbabwe. World Development, 25(7):11411149

Maslyn, J.M. \& Fedor, D.B. (1998). Perceptions of politics: Does measuring different foci matter? Journal of Applied Psychology, 83:645-653.

Mayes, T.B. \& Allen, R.W. (1977). Toward a definition of organizational politics. Academy of Management Review, 2:672-678.

Mintzberg, H. (1983). Power in and around organizations. Englewood Cliffs, NJ: Prentice-Hall.

Mintzberg, H. (1985). The organization as political arena. Journal of Management Studies, 22:133-154.

Mizunoya, S. \& Mitra, S. (2012). Is there a disability gap in employment rates in developing countries. World Development, 42:28-43.

Morbarak, M.E., Levin, A., Nissly, J.A. \& Lane, C.J. (2006). Why do they leave? Modeling child welfare workers' turnover intentions. Children and Youth Services Review, 28:548-577.

Moynihan, D.P. \& Pandey, S.K. (2007). The ties that bind: Social networks, person-organization value fit, and turnover intention. Journal of Public Administration Research and Theory, 18:205-227.

Muchinsky, P.M. \& Morrow, P.C. (1980). A multidisciplinary model of voluntary employee turnover. Journal of Vocational Behavior, 17:263-290.

Nyoni, S. (2002). Small, Micro \& Medium Enterprises (SMMEs). Policy \& Strategy Framework. Harare: Zimbabwe Publishing House.

Ohme, M. \& Zacher, H. (2015). Job performance ratings: The relative importance of mental ability, conscientiousness, and career adaptability. Journal of Vocational Behavior, 87:161-170.

Organ, D.W. (1988). Organizational citizenship behavior: The good soldier syndrome. Lexington, MA: Lexington Books.

Park, H.Y., Ofori-Dankwa, J. \& Bishop, D.R. (1994). Organizational and environmental determinants of functional and dysfunctional turnover: Practical and research implications. Human Relations, 47:353-367.

Perrewé, P.L., Brymer, R.A. \& Stepina, L.P. (1991). A causal model examining the effects of age discrimination on employee psychological reactions and subsequent turnover intentions. International Journal of Hospitality Management, 10(3):245-260

Randall, M.L., Cropanzano, R., Bormann, C.A. \& Birjulin, A. (1999). Organizational politics and organizational support as predictors of work attitudes, job performance, and organizational citizenship behavior. Journal of Organizational Behavior, 20:159-174.

Rodríguez, C.M. \& Wilson, D.T. (2002). Relationship bonding and trust as a foundation for commitment in US-Mexican strategic alliances: A structural equation modeling approach. Journal of International Marketing, 10(4):53-76.

Rosen, C.C. \& Hochwarter, W.A. (2014). Looking back and falling further behind: The moderating role of rumination on the relationship between organizational politics and employee attitudes, well-being, and performance. Organizational Behavior and Human Decision Processes, 124:177-189.

Rosen, C. \& Levy, P. (2013). Stresses, swaps, and skill: An investigation of the psychological dynamics that relate work politics to employee performance. Human Performance, 26:44-65.

Ross, G.F. (2005). Tourism industry employee work stress - a present and future crisis. Journal of Travel and Tourism Marketing, 19(2):133-147.

Saleem, H. (2015). The impact of leadership styles on job satisfaction and mediating role of perceived organizational politics. Procedia - Social and Behavioral Sciences, 172:563-569.

Schwepker, C.H. (2001). Ethical climate's relationship to job satisfaction, organizational commitment, and turnover intention in the salesforce. Journal of Business Research, 54:39-52.

Sheth, J.N. \& Parvatiyar, A. (1995). Relationship marketing in consumer markets: Antecedents and consequences. Journal of the Academy of Marketing Science Fall, 23(4):255-271.

Staw, B.M. (1984). Organizational behavior: A review and reformulation of the field's outcome variables. In Rosenzweig, M.R. \& Porter, L.W., eds. Annual review of psychology, volume 35. Palo Alto, CA: Annual Reviews, pp. 627-666.

Steensma, H., Van Breukelen, W. \& Sturm, M. (2004). Studying employee turnover by splitting up the usual comparison group. Journal of Individual Employment Rights, 11:211-227.

Steers, R.M. \& Rhodes, S.R. (1978). Major influences on employee attendance: A process model. Journal of Applied Psychology, 63:391-407.

Tett, R.P. \& Meyer, J.P. (1993). Job satisfaction, organizational commitment, turnover intention, and turnover: Path analyses based on meta-analytic findings. Personnel Psychology, 46(2):259-293.

Trevor, C.O. (2001). Interactive effects among actual ease of movement determinants and job satisfaction in the prediction of voluntary turnover. Academy of Management Journal, 44: 621-638.

Utami, A.F., Bangun, Y.R. \& Lantu, D.C. (2014). Understanding the role of emotional intelligence and trust to the relationship between organizational politics and organizational commitment. Procedia - Social and Behavioral Sciences, 115:378386. 
Van Gundy, A. (1987). Organizational creativity and innovation. In Isaksen, S.G., ed. Frontiers of creativity research. Buffalo, NY: Bearly, pp. 358-379.

Velenchik, A.D. (1997). Government intervention, efficiency wages, and the employer size wage effect in Zimbabwe. Journal of Development Economics, 53:305-338.

Vigoda, E. (2000). Organizational politics, job attitudes, and work outcomes: Exploration and implications for the public sector. Journal of Vocational Behavior, 57(3):326-347.

Vigoda, E. (2003). Developments in organizational politics: How political dynamics affect employee performance in modern work sites. Cheltenham: Edward Elgar.

Wayne, S.J., Shore, L.M. \& Liden, R.C. (1997). Perceived organisational support and leader member exchange: A social exchange perspective. Academy of Management Journal, 40(1): 82-111.

Witt, L.A., Andrews, M.C. \& Kacmar, K.M. (2000). The role of participation in decision-making in the organizational politicsjob satisfaction relationship. Human Relations, 53:341-358.

Yilmaza, E., Özer, G. \& Günlük, M. (2014). Do organizational politics and organizational commitment affect budgetary slack creation in public organizations? Procedia - Social and Behavioral Sciences, 150:241-250.

Zaheer, A., Mcevily, B. \& Perrone, V. (1998). Does trust matter? Exploring the effect of international and interpersonal trust on performance. Organization Science, 9:141-159.

Zahra, S.A. (1987). Organizational politics and the strategic process. Journal of Business Ethics, 6(7):579-587.

Zhou, J. \& George, J.M. (2001). When job dissatisfaction leads to creativity: Encouraging the expression of voice. The Academy of Management Journal, 44(4):682-696. 


\section{NOTES}

